\title{
THE ONTOGENY OF LYSSOMANES VIRIDIS (WALCKENAER) (ARANEAE: SALTICIDAE) ON MAGNOLIA GRANDIFLORA L. ${ }^{1}$
}

\author{
By David B. Richman and Willard H. Whitcomb \\ Department of Entomology and Nematology \\ University of Florida, Gainesville, Florida, 32611
}

\section{INTRODUCTION}

Lyssomanes viridis (Walckenaer) is a translucent green spider found in the southeastern United States from North Carolina to Florida and Texas (Kaston 1978). It has sometimes been placed in a separate family, Lyssomanidae, but the most recent taxonomic study (Galiano 1976) includes it in the Salticidae. This species commonly lives on the tree Magnolia grandiflora L. in mesic situations, on palmettoes in various habitats, and on Lyonia sp. and other shrubs in the sand pine scrub of central Florida. No complete life cycle has been published for any Lyssomanes species. Crane (1950) did present descriptions of the early stages, including second postembryo (her first instar) and first instar (her second instar) of $L$. bradyspilus Crane. The current paper is the result of a total of two and one half years of collection and observation of a natural population of $L$. viridis for the purpose of learning about the ontogeny of this spider in the wild.

\section{MeThODS}

Eggs, immatures, and adults of $L$. viridis were collected on the undersides of leaves by turning the leaves and catching the spiders in vials in a stand of Magnolia grandiflora at Tall Timbers Research Station, Leon County, Florida (Figure 1). These were collected monthly from August 1971 to February 1973 and usually twice a month from June 1977 through June 1978. The population densities were measured by counting the number of spiders collected per 1000 leaves from September 1977 through the death of the adults and the

'Florida Agricultural Experiment Station Journal Series No. 3059.

Manuscript received by the editor July 10, 1981 

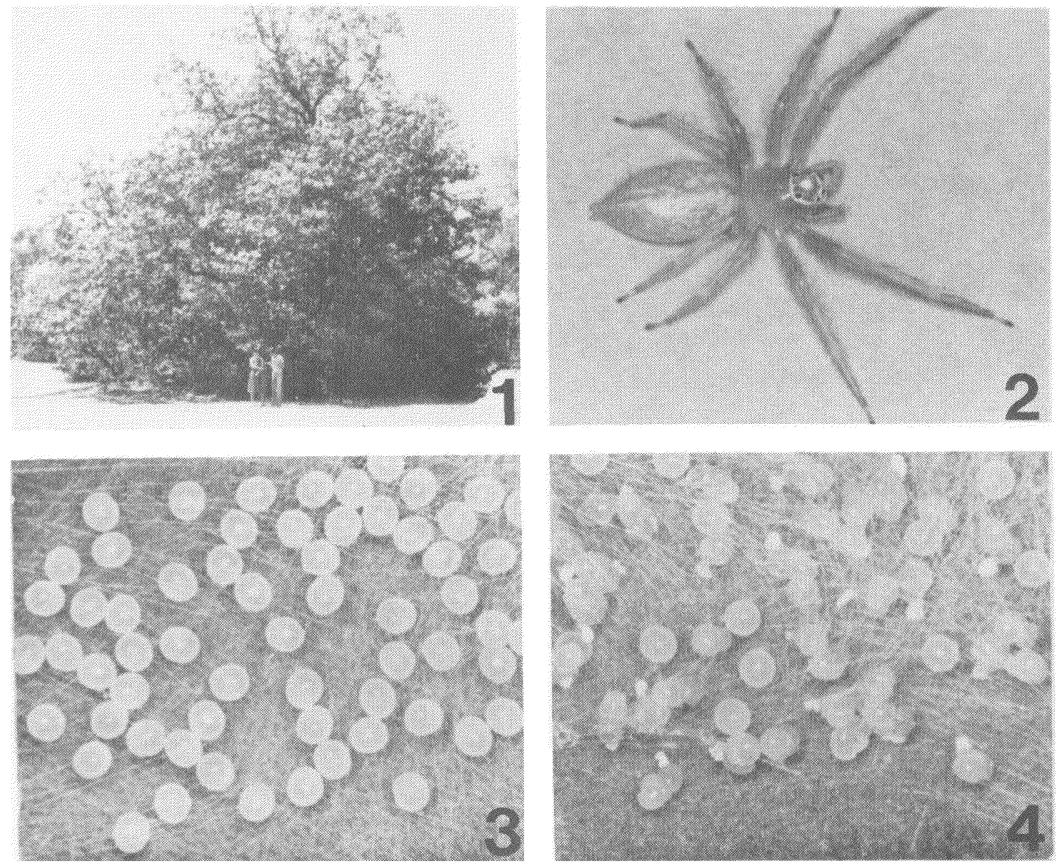

Figure 1. Magnolia stand at Tall Timbers Research Station, Leon County, Florida. Figure 2. Gravid female of Lyssomanes viridis (Walckenaer). Figure 3. Eggs of Lyssomanes viridis on underside of magnolia leaf. Figure 4. First postembryos of Lyssomanes viridis on magnolia leaf.

rise of immatures in June 1978. Leaves were counted arbitrarily as the stand was circled. Collections were made from 0 to $2 \mathrm{~m}$ above ground level on both the outside edge and within the stand. All spiders with prey were preserved separately and identifications of the prey obtained from various specialists. Carapace widths were measured using a dissecting microscope equipped with an ocular micrometer for 20 specimens per sample, if available. The number of instars was calculated by using a method of simple regression of carapace widths developed by Hagstrum (1971). It was assumed that salticids exhibit a similar mean relationship between logarithms of carapace width and stadium $(\log \mathrm{y}=0.0871 \mathrm{x}-0.2692$ where $\mathrm{x}=$ stadium and $\mathrm{y}=$ carapace width) as Lycosids, Loxoscelids, Clubionids, Oxyopids, and Ctenizids. Egg masses collected on the magnolia trees were allowed to hatch and the time spent in the first 
and second postembryonic stages was measured in the laboratory; however, these were not raised through the various instars.

Weather information for Tall Timbers was obtained from the research station. Rainfall during August 1971 to February 1973 averaged $11.4 \mathrm{~cm}(\mathrm{SD}=7.6 \mathrm{~cm})$ with $33.7 \mathrm{~cm}$ falling in June 1972 (hurricane Agnes) and only $1.6 \mathrm{~cm}$ falling in September 1972. Rainfall during July 1977 through June 1978 averaged $10.9 \mathrm{~cm}$ (SD $=4.3 \mathrm{~cm}$ ) per month with a maximum of $16.9 \mathrm{~cm}$ in August 1977 and a minimum of $3.7 \mathrm{~cm}$ in October 1977. Relative humidity almost always reached $100 \%$ at some time during the day except for a few days during the winters.

\section{Results AND Discussion}

We found that mating took place in May and that the males disappeared by mid-June. Some females lingered on at least until August. Gravid females (Figure 2) laid 25-70 eggs (mean 42.7, $\mathrm{SD}=11.6$, no. $=24$ ) at a height of $33-131 \mathrm{~cm}$ (mean $87.9, \mathrm{SD}=28.0$, no.=12) on the magnolia stand from May 31 to July 6. Second clutches may have been produced only occasionally as females usually guarded the eggs until first instar and females laid second clutches only twice (infertile) in the laboratory (not included in egg counts). The bright green eggs (Figure 3) were ca. $1 \mathrm{~mm}$ in diameter and were loosely covered by silk (there was no distinct cocoon). The first postembryonic stage (Figure 4-chorion molted) lasted 32-35.5 hours (no. of egg masses $=4$ ) and the second postembryonic stage (legs free of vitelline membrane) lasted 7 days (no. of egg masses = 5). The carapace widths (Figure 5) indicated that there were probably 7 instars including adult female after second postembryo, based on Hagstrum's (1971 Figure 1) data for laboratory reared Lycosidae, Loxoscelidae, Clubionidae and Oxyopidae and for field collected Ctenizidae. Males may have one less instar than females. The immature stage individuals lasted from June to the next May when most matured (Figure 5). Spiderling first instars occurred from June to July, most individuals reaching second instar by the first of August. The majority reached third to fourth instar in September and passed through the winter as third to fifth instars. The female's sixth, or penultimate, instar started to be evident in March. Courtship was observed by Richman (in press).

Immature spiders, especially early instars, fed primarily on 


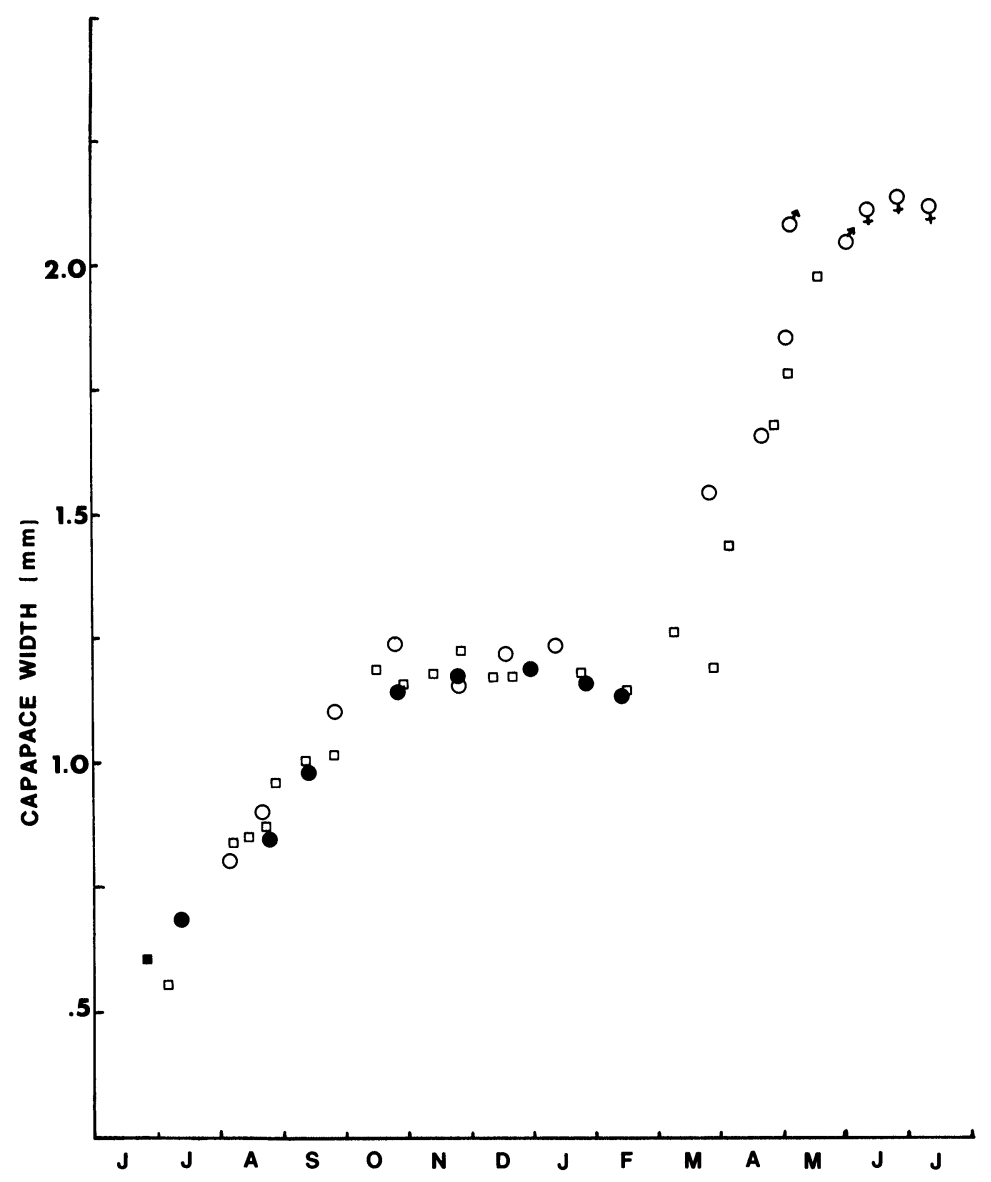

Figure 5. Mean carapace width of immature and adult Lyssomanes viridis (Walckenaer) at Tall Timbers, Leon County, Florida 1971-1973 and 1977-1978. Open circles $=1971-1972$, closed circles $=1972-1973$, open squares $=1977-1978$, closed square $(1)=1978$ broods. Sex symbols indicate males and females for 1971-1972 and 1977-1978.

midges of the family Chironomidae. Adults and large immatures tended to take larger prey, such as syrphid and dolichopodid flies. Of 12 prey records, immatures were found with 3 chironomids, (one identified as Orthocladiini by A. R. Soponis), 1 chaoborid fly, 1 syrphid fly (genus Toxomerus identified by H. V. Weems), 1 


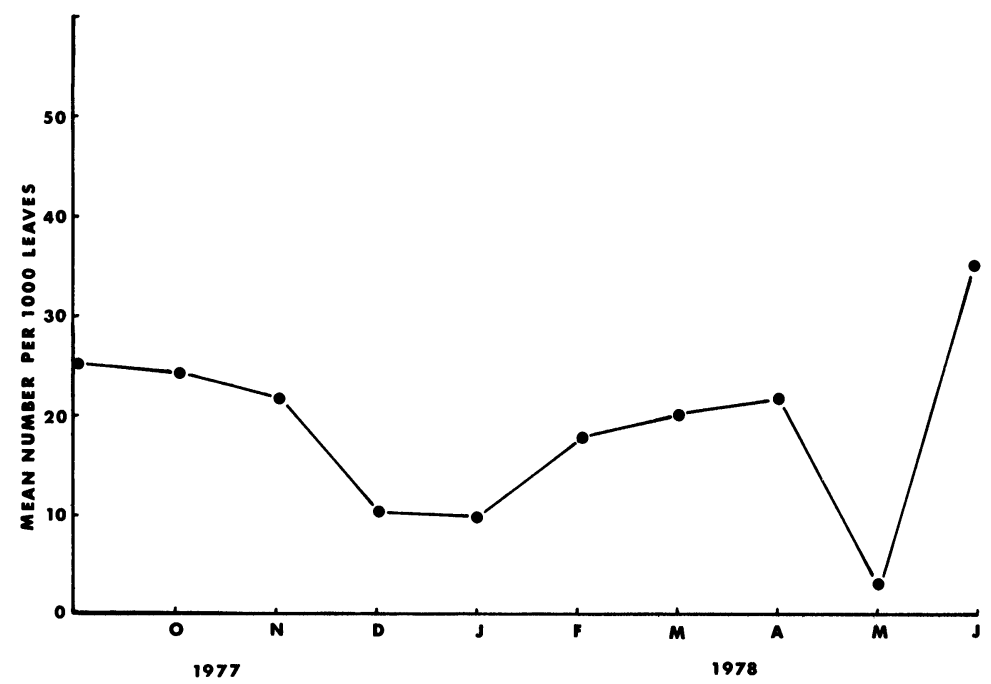

Figure 6. Population densities of Lyssomanes viridis (Walckenaer) in magnolia stand at Tall Timbers fall 1977 to spring 1978. Data points are means between surveys made both inside and outside the stand, during the last half of each month.

encyrtid wasp and 1 aphid (genus Macrosiphon identified by H. A. Denmark). Adult males were collected with an unknown dipteran and a salticid spider of the genus Hentzia. Adult females were collected with a dolichopodid fly, an unknown dipteran and a psocid.

The population density (Figure 6) dropped during the winter, but rose in the spring nearly to that of the previous fall, probably reflecting inactivity during the winter, rather than a significant mortality. The population drop during May is probably a result of the death of adults. Adults were only found during the spring and early summer.

Some adult spiders were found in the nest of a mud dauber of the genus Trypoxylon by G. B. Edwards at Newnan's Lake, Alachua County, Florida. A large Trypoxylon was observed during June at Tall Timbers and a fresh nest was found on the underside of a magnolia leaf. The nest in this case was filled with Araneidae. One adult female $L$. viridis was collected and found to have a large mirmithid nematode in its abdomen. No egg parasites were seen. Complete life histories have been published for several salticids, 
notably Philaeus chrysops Poda (Bonnet 1933), three species of Corythalia (Crane 1948) and Phidippus johnsoni Peckham and Peckham (Jackson 1978). Female $P$. chrysops generally had seven molts (six instars) before maturity, and this was also true of the three species of Corythalia observed by Crane (1948). Jackson (1978) reported 6-9 molts for $P$. johnsoni. Thus, the life cycle of $L$. viridis seems to compare well with those of other salticids.

\section{SUMMARY}

A population of the salticid spider Lyssomanes viridis (Walckenaer) was sampled for two and one half years on a stand of Magnolia grandiflora L. trees in North Florida. Mating took place in May and adult males disappeared by mid-June. Females laid 25-70 eggs per clutch mostly during June. These hatched from June to July and the immatures overwintered in middle instars. After temperatures increased in the spring the spiders rapidly developed to adults. Simple linear regression of the carapace widths indicated that this species has a total of seven instars from the end of second postembryo through adult female. Males may have one fewer instar. L. viridis feeds primarily on Diptera in this habitat.

\section{ACKNOWLEDGEMENTS}

We would especially like to thank Dr. Bruce Means and Ed and Roy Komarek of Tall Timbers Research Station for their help and support. Also we would like to thank Dr. Robert C. Hemenway, Jr., Dr. G. B. Edwards, and Dr. Barbara Saffer for their help in collecting specimens in the magnolia stand.

\section{Literature Cited}

\section{BONNET}

1933. Cycle vital de Philaeus chrysops Poda (Araneide, Salticide). Arch. Zool. Exp. Gen. 75: 129-44.

Crane, J.

1948. Comparative biology of salticid spiders at Rancho Grande, Venezuela. Part I. Systematics and life history in Corythalia. Zoologia 33: 1-38.

1950. Comparative biology of salticid spiders at Rancho Grande, Venezuela. Part V. Postembryonological development of color and pattern. Zoologica 35: 253-61. 
Galiano, M.E.

1976. Comentarios sobre la categoria sistematica del taxon "Lyssomanidae" (Araneae). Rev. Mus. Argentino Cienc. Natur. Entomol. 5: 59-70.

Hagstrum, D.W.

1971. Carapace width as a tool for evaluating the rate of development of spiders in the laboratory and the field. Ann. Entomol. Soc. Amer. 64: 757-60.

JACKSON, R.R.

1978. Life history of Phidippus johnsoni (Araneae, Salticidae). J. Arachnol. 6: $1-29$.

KASTON, B.J.

1978. How to know the spiders. 3rd Ed. Wm. C. Brown, Dubeque. 272 p. Richman, D.B.

(in press). Epigamic display in jumping spiders (Araneae, Salticidae) and its use in systematics. J. Arach. 

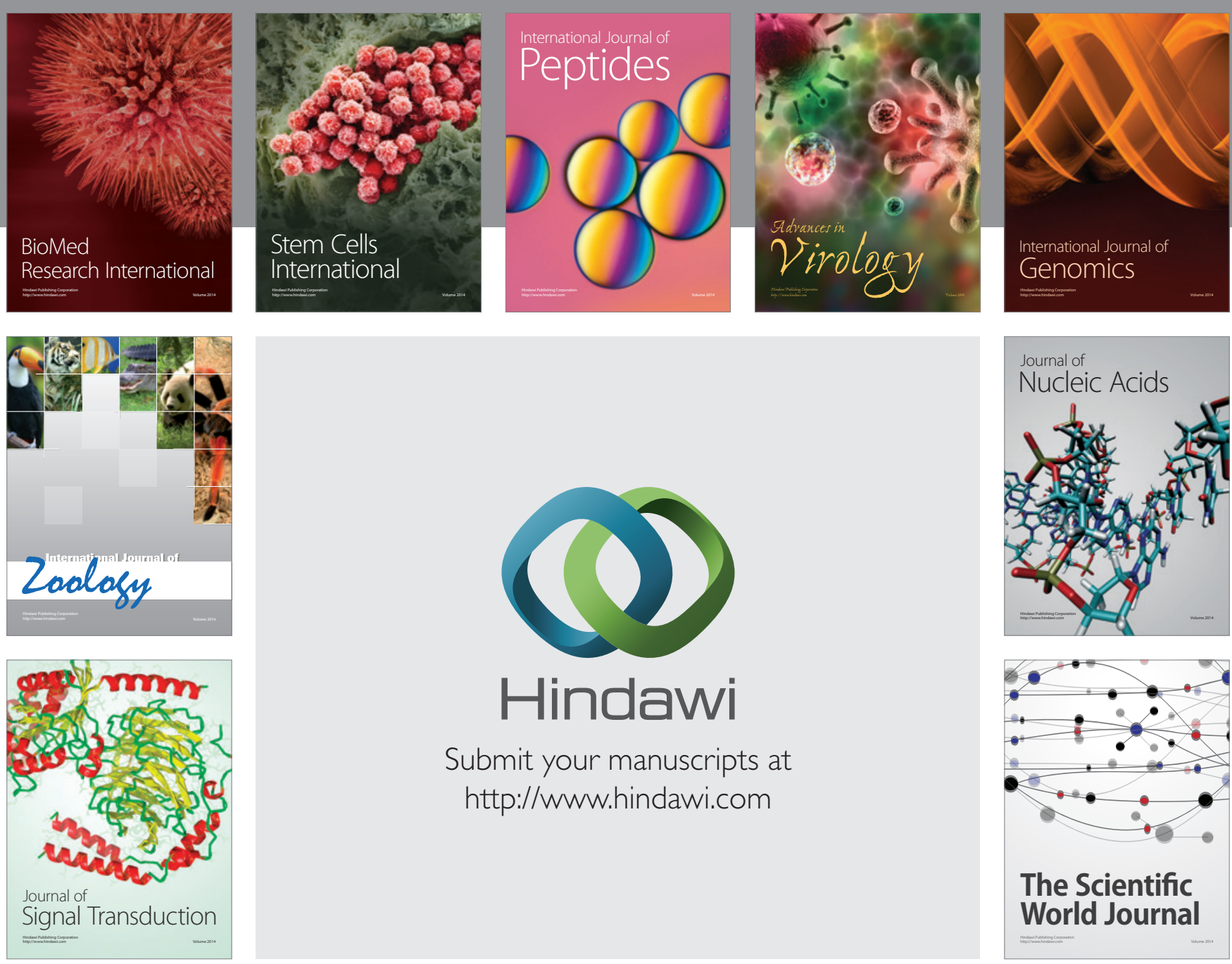

Submit your manuscripts at

http://www.hindawi.com
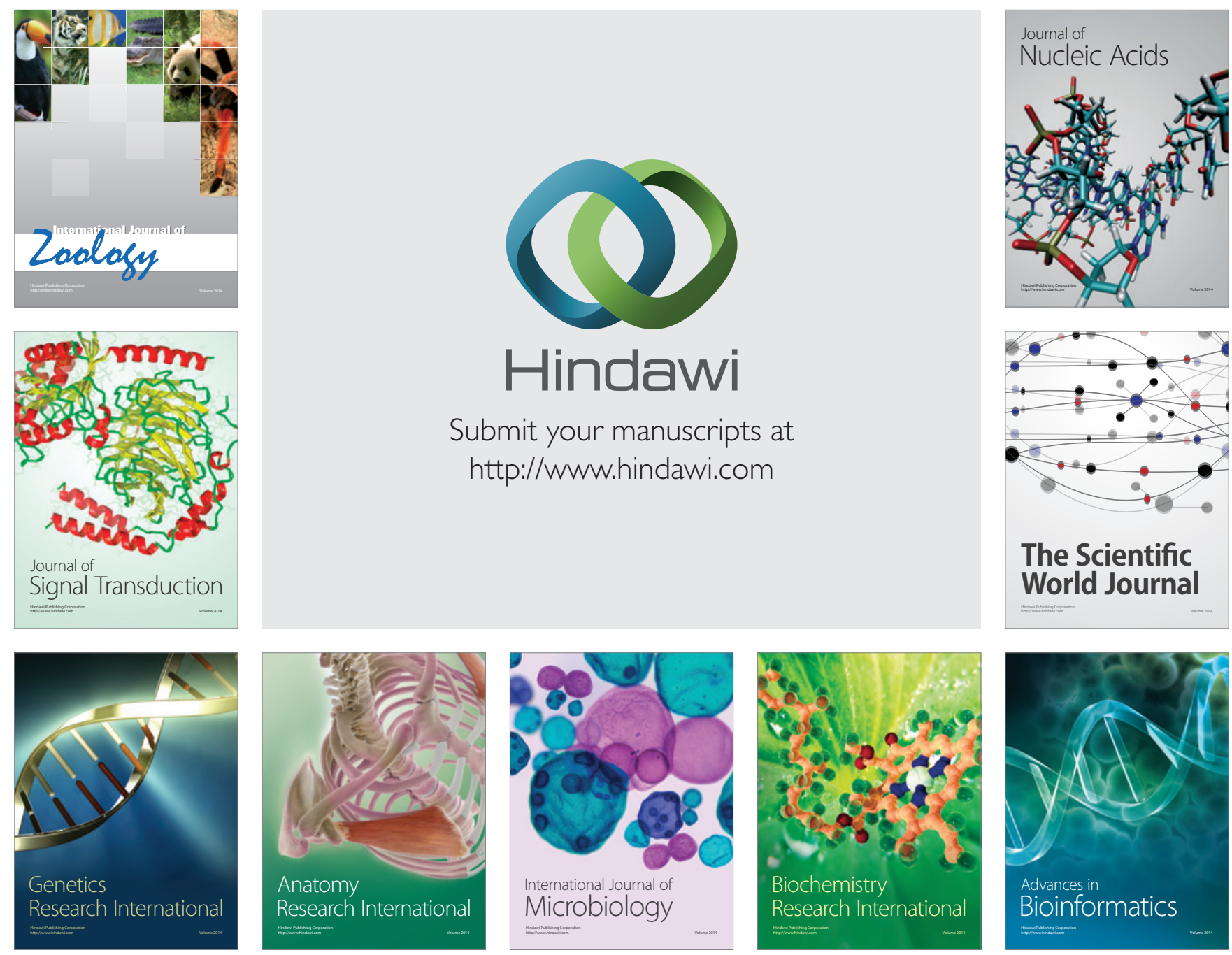

The Scientific World Journal
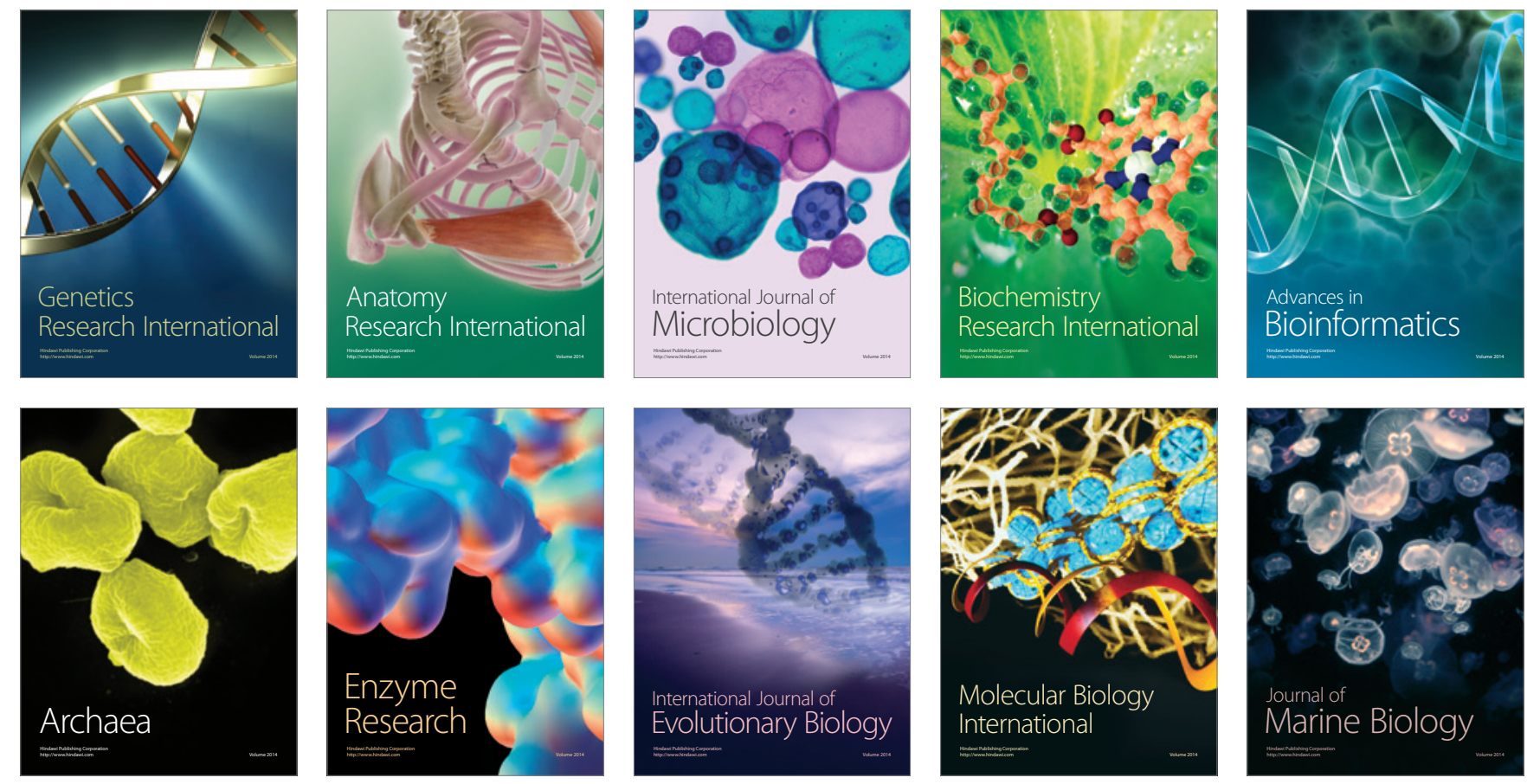